\title{
GASTRONOMIC MANIFESTATIONS AS A FACTOR OF IMPROVEMENT OF SERBIA'S TOURISM OFFER
}

\author{
Tanja Stanišićl, Marija Kostić², Milena Mišeljic ${ }^{3}$
}

\begin{abstract}
Summary
Under the influence of globalization and mass settlement of cities and urban areas, nostalgia for traditional and rural is increasingly felt. All this supports the development of manifestation and gastronomic tourism and the promotion of autochthonous products and traditions. Serbia is a country where a large number of national minorities lives, each of which has an impact on the gastronomy of the some area. The combination of all the cuisines and the diversity of tradition made Serbian dishes unique. There are a large number of events in the tourism offer of Serbia, which themes are gastronomic products. Manifestations, as a kind of promotion of a particular area, are becoming more and more popular. The paper analyses gastronomic manifestations as an important segment of Serbia's tourism offer. The methods applied in the paper are the method of correlation and comparative analysis. The results of the research indicate a positive interdependence between the number of manifestations and tourist traffic during the year, while the existence of an interdependence between the number of manifestations and tourist traffic in the regions was not recorded.
\end{abstract}

Key words: manifestations, gastronomy, tourism

JEL: $Z 320$

\section{Introduction}

There are numerous manifestations that have food for the basic topic. Food festivals as a form of food tourism can play an important role in presenting new tastes to tourists, as well as learning about different customs. Tradition in preparing food is passed

1 Tanja Stanišić, Ph.D., Assistant Professor, University of Kragujevac, Faculty of Hotel Management and Tourism in Vrnjačka Banja, Vojvođanska Street n.n., 36210 Vrnjačka Banja, Serbia, Phone: +381 64 8199022, E-mail: tanja.stanisic@kg.ac.rs

2 Marija Kostić, Ph.D., Assistant Professor, University of Kragujevac, Faculty of Hotel Management and Tourism in Vrnjačka Banja, Vojvođanska Street n.n., 36210 Vrnjačka Banja, Phone: +38164 8199009, E-mail: marija.kostic@kg.ac.rs

3 Milena Mišeljić, Ms.C., Agency for Education “Academy” Čačak, Vojvode Stepe 44, 32000 Čačak, Serbia, Phone: +381 64 2172648, E-mail: $\underline{\text { m85milena@yahoo.com }}$

EP 2018 (65) 1 (111-124) 
down from generation to generation, thus becoming the cultural good of the people. Thanks to gastronomic tourism, tradition is preserved and it is trying to bring domestic food to many tourists from neighbouring cities, as well as foreign tourists. In the era of globalisation, localisation and the use of gastronomy and food can be a source of regional and national identity (Hjalager, Richards, 2002). Every region in Serbia has a specific dish or an agricultural product that makes it recognizable. However, a festival that simply contains a food component can not be classified as a food festival. The food festival is a festival with food that emphasizes regional or local food specialties or a festival on the theme of food, which has food-related activities and programs or food topics. Food festival is a place where communities are engaged in public celebration and promotion of local food (Everett, Aitchison, 2007). With the changes regarding the preferences of local and international tourists, the traditional concept of holiday is also changing (Sanin, Aydin, 2017, p. 181). Food festivals are one of the ways of completing the experience of more and more demanding tourists.

The term gastronomy is in most cases linked to the consumption of food in restaurants. However, the trends of gastronomic tourists today include visiting and tasting food and drinks at primary and secondary producers, the presence of food and drink manifestations and the consumption of authentic dishes and drinks. Gastronomic tourists becomes a viable alternative for new destinations that cannot benefit from "sun, sea, and sand," or natural or cultural resources (Kivela, Crotts, 2005, p. 41). Food at manifestations is a very powerful means of communication with tourists, because visitors to these events can socialize and engage in cultural activities, such as visits to art galleries, historic sites or parks, to find hidden gastronomic treasures known only to local people, try unusual dishes and food and get acquainted with a particular culture or tradition (Bjeljac, 2010, p. 128). Therefore, gastronomic tourism and gastronomic events are compatible with other forms of tourism and tourist values. Through gastronomy, other forms of tourism are connected.

The subject of the paper is the analysis of gastronomic manifestations in the tourism offer of Serbia and the perception of the possibilities for their popularization. The aim of this paper is to prove, based on the analysis of available information and data, as well as the results of the research on gastronomic manifestations and their connection with tourist traffic, that gastronomic tourism in Serbia should be developed both due to the volume of resources available in Serbia and the possibility of a positive impact on the growth of tourist traffic. In order to achieve the stated goal of the research, the authors of the paper proceed from the basic assumption of the existence of a positive interdependence between the number of manifestations and the realized tourist traffic.

\section{Theoretical concept of gastronomic tourism}

Gastronomy includes all that relates to cooking, cooking skills, and in this regard, in a wider sense, includes gourmand, gourmet, and in the broadest sense, the connection between culture and food, art nutrition, culinary art. Gastronomy therefore refers to rules or norms in respect of eating and drinking (Santich, 2004, p. 18). The relationship 
between tourism and gastronomy is a long-standing and close one (Correia et al., 2008, p. 164). Gastronomy can add value to the tourist experience and is associated with quality tourism for travellers in search of new products and experiences that yield a high level of satisfaction (Kivela, Crotts, 2009, p. 163). In considering gastronomy as a motive for tourist movements, it is necessary to define several concepts: food tourism, culinary tourism and gastronomic tourism (Vukić, 2015, p. 120). Some authors define food tourism as a visit to primary and secondary food producers, food festivals, restaurants and all those locations that are the motive for food tasting. The term culinary tourism is in line with the concept that tourists can experience another culture through food, i.e. culinary tourism is research participation in the consumption, preparation and presentation of food, local cuisine and menus. It is considered that gastronomic tourism is every journey that is at least partly motivated by the interest in food and drink or consumption of food and drink. Gastronomic tourism can also be viewed as a subset of cultural tourism (the cuisine is part of the culture) (Kalenjuk et al., 2011).

Gastronomic tourism is also defined as the activity of researching and discovering culture and history through food, which influences the creation of unforgettable experiences (Kalenjuk et al., 2015). Regions in which technological waves and globalization have not significantly affected changes in the way food and beverage production, but also the culture of their consumption have become favourable for the development of a selective form of tourism known globally under the names of food and beverage tourism, culinary tourism, gastronomic tourism, gourmet tourism (Hall, Mitchell, 2002). Gastronomic tours, arranged to introduce a region's dishes and food culture which plays an important role in the selection of and the experience tourists can have in a region, can feature a region (Sormaz, 2016, p. 728). Gastronomic tourism, in which focus is the local cuisine of the destination as the primary attraction, is one of the relatively small niches in modern tourism. This type of tourism offers a holistic experience that includes various factors, such as atmosphere, price and quality, which are also the determinants of consumer satisfaction (Correia et al., 2008). The culinary tourism experience has been noted as having multiple valuable effects on the territory and its products, such as increased awareness, loyalty, emotional connection, increased involvement and brand differentiation (Mason, Paggiaro, 2012, p. 1330). Gastronomic tourism is a niche of tourism that has grown rapidly, so it represents a new opportunity in a market that can enhance the attractiveness of the destination without introducing some new major products.

Gastronomic tourism is a possible competitive advantage and can be an essential element in branding the country or region. A clearly defined gastronomic identity and heritage can be exploited in the key processes of differentiation and rejuvenation, helping to convey a unique sense of place (Fox, 2007). Tourist spending can stimulate local gastronomy and be an instrument for improving agriculture and food production. 


\section{Gastronomic manifestations as a tourism product}

Gastronomic manifestations or food events, sometimes called special or hallmark events, are fairs, festivals, cultural and industrial events that take place regularly or from time to time. Food-related festivals are an easy way to animate members of the local community, as well as visitors of all ages because of the great role which food plays in everyday life, and which is not only a factor of survival, growth and development, and performing daily activities, but also contributes to better quality of life (Kostić, Petrović, 2015). The food and drink manifestations include all manifestations that are associated with, of course, food and drink, or making and selling some traditional gastronomic recipes of a particular area or presenting local drinks like wine and brandy.

Numerous food manifestations have appeared around the world, with growing interest in gastronomic tourism, becoming a very interesting form of recreation and tourist attractions. The destination can be further promoted, such as the destination for wine tourism by the development of wine manifestations (Wargenau, Che, 2008). Local food provides a gateway into a destination's intangible heritage (Björk, Kauppinen-Räisänen, 2014, p. 298). Food festivals are a great opportunity for the destination for many reasons. For food and wine producers, these festivals provide a cheap and sometimes profitable way to promote brands to new consumers and provide opportunity to interact with consumers as well as their feedback. For tourism destinations, gastronomic and wine manifestations are a chance to gain awareness about regional brands, promote the region to which a certain type of gastro-product is related, but also a reason for re-visits to a particular region (Vukić, 2015, p. 128).

Gastronomic manifestations as a subtype of cultural events are of particular importance, enriching the tourism offer, which can extend the tourist season, protect and enhance cultural values of destinations. Gastronomic manifestations attract a large number of visitors, both domestic and foreign tourists (Čatić, 2016, p. 47). The accompanying manifestations are expositions (arts, old mechanization, new agricultural machines and tools), sports competitions, entertainment programs, folklore evenings, agricultural conferences, etc.). Manifestations can be included in the package of arrangements of some tour operators or travel agencies, whether it is a manifestation within the borders of the state for which the package arrangement was created or organizing a trip to another country to attend a particular event (Vrančić, 2016, p. 31).

Manifestations can contribute to the completion of the tourism product of rural tourism. The importance of rural tourism is reflected in the very important interaction of agricultural production, traditional agricultural food products, presentation of tradition, traditional gastronomy and tourist services (Cvijanović, Ružić, 2017, p. 33). The process of identifying events and creating an integrated rural tourism product should be implemented by the local community together with local tourism organizations, with the strategic and financial support of government and local institutions, taking into account that the state should create a desirable environment for the promotion of a particular concept of development (Radović et al., 2012). Traditional food is the reason 
for the loyalty of tourists and affects positively the development of a rural destination (Vujko et al., 2017, p. 477). At the same time, gastronomic experiences can add value to tourism by providing a link between local culture, landscape and food, and creating an atmosphere that is so important for an unforgettable vacation experience (Hjalager, Richards, 2002).

Manifestations strengthen the image and recognizability of the place as a gastronomic destination. The aim of this event, apart from publicity and achieving economic results, is primarily the introduction of a society with products of the local population, autochthonous gastronomy and tradition (Štimac, 2016, p. 41). Numerous marketing instruments can be used to promote events in Serbia. The creation of logos and slogans of the manifestation, the production of informative material and their distribution, advertising, sponsorship and support of events, presentations at specialized tourism fairs, the Internet as a form of communication with potential visitors of the event are just some of them.

Potentially attractive for tourist visits are also events dedicated to the culinary heritage of the Serbian population, that is, gastronomy. In one part of the scientific expert public, the media, and other public opinion, this type of manifestation is often called "ijade". By this approach and the name, these manifestations are often disdained and underestimated and their significance is reduced (Bjeljac, 2010, p. 96). There are a vast number of gastronomic festivities that are considered to be an important part of the tourist offer of destinations or even regions in Serbia (Bjeljac et al., 2016, p. 16). Every region in Serbia has some gastronomic product that is a trademark and by which local tourist organizations try to attract guests. In November 2011, the Tourism Organization of Serbia presented a brochure "Soul Food" written in English at the Tourism Fair in Berlin, featuring gastronomic products by region. This is yet another step forward in presenting the rich offer of national dishes and drinks that Serbia has abundantly. With this kind of marketing, it can be expect a greater interest of foreign tourists who will decide to spend part of their vacation in the rural areas of Serbia and enjoy traditional dishes and drinks (Stojanović, 2013, p. 39).

\section{Quantitative analysis of gastronomic manifestations in the tourism offer of Serbia}

Based on the publication "Events 2017", issued by the National Tourism Organisation of Serbia, which includes tourist events, fairs, cultural, sports, business and other events, organized with various reasons and with various contents and which enrich the tourist offer of Serbia, quantitative analysis of gastronomic manifestations in the tourism offer of Serbia is conducted.

According to the events calendar, a total of 817 events was scheduled during 2016 in Serbia. In 2017, this number is higher and amounts to 829 manifestations (National Tourism Orgnization of Serbia, 2017). Based on the analysis of the calendar, it can be highlighted the fact that in Serbia there are currently 241 gastronomic manifestations, where food is the main motive of manifestations or appears as additional content. 
When organizers of manifestations are observed, they can be divided into 7 groups (Table 1.).

Table 1. Organizers of gastronomic manifestations in Serbia

\begin{tabular}{|l|c|c|}
\hline \multicolumn{1}{|c|}{ Organizers } & \multicolumn{2}{c|}{ Manifestations } \\
\cline { 2 - 3 } & Number & Share \\
\hline Citizens' associations & 17 & $7 \%$ \\
\hline Tourism organizations, municipalities, offices for tourism & 93 & $39 \%$ \\
\hline $\begin{array}{l}\text { More organizers (tourism associations, various clubs and societies, tourist } \\
\text { organizations and companies) }\end{array}$ & 12 & $5 \%$ \\
\hline $\begin{array}{l}\text { Associations, organizations (associations of beekeepers, livestock farmers, } \\
\text { winemakers, bakers) }\end{array}$ & 30 & $12 \%$ \\
\hline Cultural centres & 21 & $9 \%$ \\
\hline Local communities & 20 & $8 \%$ \\
\hline $\begin{array}{l}\text { Fairs and festivals (Belgrade fair, Šumadija fair, wineries, cultural network, Novi } \\
\text { Sad fair, cheese festival) }\end{array}$ & 15 & $6 \%$ \\
\hline $\begin{array}{l}\text { Others (tourist agencies, tourist companies, tourist-sports centres, chambers, } \\
\text { schools...) }\end{array}$ & 33 & $14 \%$ \\
\hline
\end{tabular}

Source: National Tourism Organisation of Serbia, 2017

The largest number of gastronomic manifestations in the tourist offer of Serbia is organized by tourism organizations (39\% of the total number of manifestations, or 93), followed by other organizers, with $14 \%$ and 33 manifestations. Various associations and organizations, with $12 \%$ and 30 events are at the third place. Following are cultural centres with $9 \%$ or 21 manifestations, local communities with 20 manifestations which make up $8 \%$, citizens' associations with 17 events - 7\%, fairs and festivals make up $6 \%$, or 15 manifestations and the least number of events ( $5 \%$ or 12 manifestations) is organized by groups that make up more organizers.

When the duration of manifestations is analysed (Graph 1.), the most are those that last one day. There are 124 one-day gastronomic manifestations in Serbia, which is $51 \%$ of the total number of manifestations. They are followed by two-day ones (50 manifestations, or $21 \%$ ). The following are three-day manifestations (41 manifestations, or $17 \%$. The least number of manifestations, only 26 manifestations or $11 \%$, lasts for four days or more (mostly fairs and grape harvesting). 
Graph 1. Duration of gastronomic manifestations in Serbia

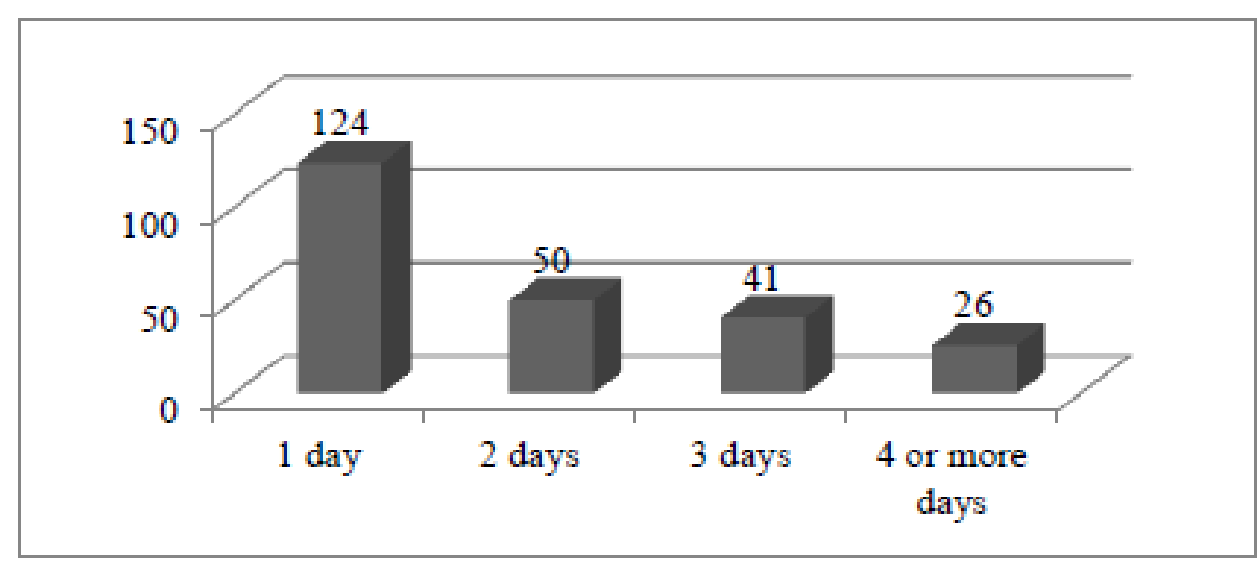

Source: Authors' presentation based on National Tourism Organisation of Serbia, 2017

Gastronomic manifestations are held throughout the year, but mostly during the summer and autumn months (Graph 2.).

Graph 2. Number of gastronomic manifestations in Serbia by months

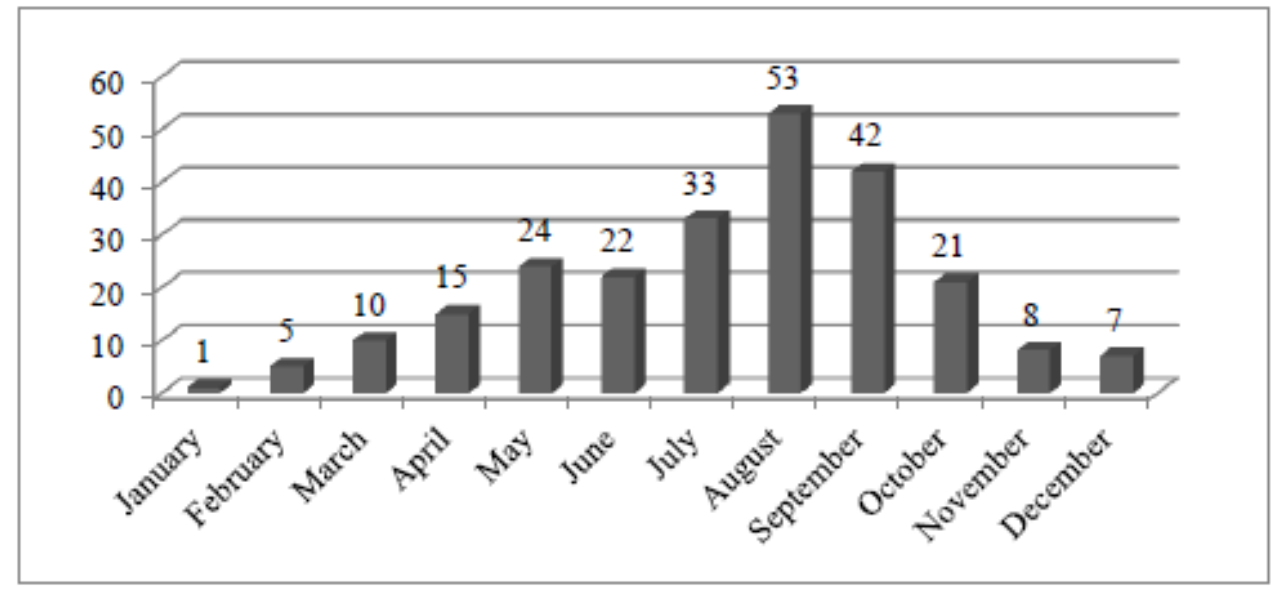

Source: Authors' presentation based on National Tourism Organisation of Serbia, 2017

In order to perceive the potential link between the number of gastronomic manifestations and the number of tourists, a comparative overview of the number of gastronomic manifestations and the total number of tourists in the Republic of Serbia by months is given in Table 2 (Statistical Office of the Republic of Serbia, 2017). 
Table 2. Comparative overview of the number of gastronomic manifestations and the total number of tourists in the Republic of Serbia by months

\begin{tabular}{|c|c|c|}
\hline Months & $\begin{array}{c}\text { Number of } \\
\text { manifestations }\end{array}$ & $\begin{array}{c}\text { Tourist arrivals (in } \\
\text { 000) }\end{array}$ \\
\hline January & 1 & 150.5 \\
\hline February & 5 & 166.7 \\
\hline March & 10 & 178.7 \\
\hline April & 15 & 222.9 \\
\hline May & 24 & 292.4 \\
\hline June & 22 & 252.7 \\
\hline July & 33 & 287.5 \\
\hline August & 53 & 323.6 \\
\hline September & 42 & 253.9 \\
\hline October & 21 & 245 \\
\hline November & 8 & 177.5 \\
\hline December & 7 & 202.2 \\
\hline
\end{tabular}

Source: National Tourism Organisation of Serbia, 2017; Statistical Office of the Republic of Serbia, 2017

Table 3 shows the calculated value of the correlation coefficient between the number of gastronomic manifestations and the number of tourists per months. Given the available size of the sample, Spearman's correlation coefficient of rank was chosen as an adequate indicator. This indicator belongs to a group of non-parametric indicators, whose application does not require the fulfilment of certain assumptions (first of all, the distribution normality) which requires the calculation of parametric indicators (Janković-Milić, 2016, 79).

Table 3. Correlation coefficient between the number of gastronomic manifestations and the total number of tourists per months

\begin{tabular}{|l|l|l|r|}
\hline \multicolumn{2}{|l|}{} & \multicolumn{1}{c|}{$\begin{array}{c}\text { Tourist } \\
\text { arrivals }\end{array}$} \\
\hline Spearman's rho & $\begin{array}{l}\text { Number of } \\
\text { manifestations }\end{array}$ & Correlation Coefficient & $\mathbf{0 . 9 5 1 ( * * )}$ \\
\hline & & Sig. (2-tailed) & 0.000 \\
\hline & & $\mathrm{N}$ & 12 \\
\hline
\end{tabular}

Note: ** Correlation is significant at the 0.01 level (2-tailed).

Source: Authors' calculation (SPSS Statistics 19)

Based on the calculated value of Spearman's correlation coefficient, it can be concluded that there is a high positive interdependence between the number of gastronomic manifestations in Serbia and the total number of tourists per months. The most visited months of the year are also the months in which the largest number of gastronomic manifestations is held. 
According to the geographical schedule, observed by the statistical regions of the Republic of Serbia, gastronomic manifestations can be grouped into manifestations in Šumadija and Western Serbia, Southern and Eastern Serbia, Vojvodina and Belgrade. In the territory of Vojvodina, 39\% of gastronomic events are organized from the total number, or 95 manifestations. In Šumadija and Western Serbia, 68 manifestations (28\%) are organized, in Southern and Eastern Serbia, 64 manifestations (27\%), while only 14 events are organized in Belgrade, or 6\% (Graph 3.).

Graph 3. Geographical schedule of gastronomic manifestations

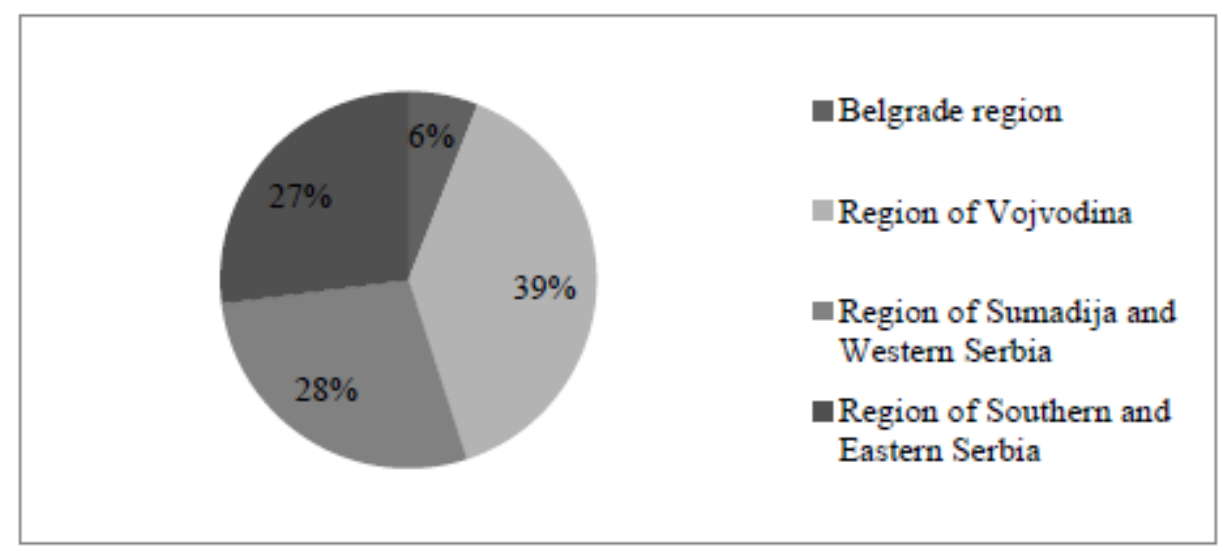

Source: Authors' presentation based on National Tourism Organisation of Serbia, 2017

In order to perceive the potential link between the number of gastronomic manifestations and tourist visits of the region in Serbia, Table 4 gives a comparative overview of the percentage share of the number of gastronomic manifestations and the total number of tourists in the Republic of Serbia by region (Statistical Office of the Republic of Serbia, 2017a).

Table 4. Comparative overview of the percentage share of the number of gastronomic manifestations and the total number of tourists in the Republic of Serbia by region

\begin{tabular}{|l|c|c|}
\hline & $\begin{array}{c}\text { Number of } \\
\text { manifestations (\%) }\end{array}$ & $\begin{array}{c}\text { Tourist arrivals } \\
\mathbf{( \% )}\end{array}$ \\
\hline Belgrade region & 6 & 33.2 \\
\hline Region of Vojvodina & 39 & 16.2 \\
\hline Region of Šumadija and Western Serbia & 28 & 36.2 \\
\hline Region of Southern and Eastern Serbia & 27 & 14.4 \\
\hline
\end{tabular}

Source: National Tourism Organisation of Serbia, 2017; Statistical Office of the Republic of Serbia, 2017a

Based on the review of the data presented in Table 4, it can be concluded that there is no interdependence between the number of gastronomic manifestations and the number of tourists by regions in Serbia. This is confirmed by calculating the Spearman's correlation coefficient in Table 5. 
Table 5. Correlation coefficient between the percentage share of the number of gastronomic manifestations and the total number of tourists by regions

\begin{tabular}{|l|l|l|r|}
\hline \multicolumn{2}{|l|}{} & \multicolumn{1}{c|}{$\begin{array}{c}\text { Tourist } \\
\text { arrivals }\end{array}$} \\
\hline Spearman's rho & $\begin{array}{l}\text { Number of } \\
\text { manifestations }\end{array}$ & Correlation Coefficient & $\mathbf{0 . 0 0 0}$ \\
\hline & & Sig. (2-tailed) & 1.000 \\
\hline & & $\mathrm{N}$ & 4 \\
\hline
\end{tabular}

Source: Authors' calculation (SPSS Statistics 19)

The value of Spearman's correlation coefficient in Table 5 points to the absence of any interdependence between the number of gastronomic manifestations and the number of tourists by region in Serbia. Those regions that absorb the highest number of tourist arrivals are not the same regions in which the largest number of gastronomic manifestations are held.

\section{Conclusion}

Attractive and diverse natural environment, authentic gastronomy and cultural heritage, cities as tourist motives are great development opportunities of Serbia in designing tourist offer. In this, the role of manifestations is very important, which are often the only driver of social life in smaller communities. The number of events in Serbia is growing every year, but it is assumed that in the coming period, the number of manifestations useful for the development of tourism will be even greater. In the calendar of events, 829 events were presented in the tourist offer of Serbia for 2017. These are the more visited and manifestations of tradition. In practice, this number is higher because there are a large number of local events that do not have marketing support. Serbia has a favourable geographical position, which favours the development of manifestation tourism, both at the regional and international level. Also, a large number of foreign companies operate in Serbia, which have the opportunity to present their products and services at various gatherings, fairs and festivals. Events in Serbia are also recognized in the relevant strategic documents as tourism products of special importance for the tourism development, in the second place there are manifestations/events (cultural, sports, etc.), immediately after the tourism of cities. All this speaks in favour of the fact that Serbia has great potentials for the development of manifestation tourism.

Food can serve as a means of branding one country. Gastronomic manifestations, which are common in rural areas, are the true protectors of tradition and perfectly reflect the typical food and lifestyle of certain nations. Therefore, these manifestations are priceless in preserving traditional food, agriculture, old crafts, wealth of folklore, national costumes and folk festivities. Gastronomic events are a unique opportunity when visitors can enjoy the local specialities prepared in the traditional manner, as well as in traditional dance and music. Some manifestations attract more visitors than there are residents in the place of the event. A smaller number is of an international character, 
which is also of greater importance because local food and drinks are presented to tourists who for the first time meet with Serbian tradition.

The basic question is whether Serbia is using its gastronomic wealth and the fact that such a small area offers so many different foods sufficiently. The results of the research in this paper pointed to the fact that the largest number of gastronomic manifestations in Serbia is organized in those months when the country attendance is the highest, that is, there is a positive interdependence between the number of gastronomic manifestations and the number of tourists per months. However, the second part of the analysis showed that those regions where most of the gastronomic events are organized are not the regions with the largest tourist traffic. According to this fact, the starting assumption of the research can not be considered confirmed. Realized tourist traffic in Serbia is not directly related to the number of gastronomic manifestations. The biggest problem in the popularization of gastronomic manifestations as a tourism offer is the lack of adequate policies and strategies for their development, insufficient promotion, insufficient investment and lack of interest of potential participants. For the development of manifestation tourism, it is also necessary to improve the tourist infrastructure and suprastructure. Also, support of travel agencies and tour operators is necessary, in the form of offer of tourist arrangements that organize visits to gastronomic events. With an adequate policy and strategy, gastronomic events can be the drivers of a successful development of manifestation tourism in Serbia.

\section{Literature}

1. Bjeljac, Ž. (2010): Turističke manifestacije u Srbiji, Geografski institut „Jovan Cvijić“, Srpska akademija nauka i umetnosti, Beograd, Srbija.

2. Bjeljac, Ž., Petrović, M., Terzić, A. (2016): Gastronomic events as a part of tourist offer: a case study of Serbia, Book of proceedings of IV International scientific-practical conference Sustainable development of tourism market: International practice and Russian experience, Stavropol, Russia, 11-16 March, 2016, pp. 12-17.

3. Björk, P., Kauppinen-Räisänen, H. (2014): Culinary-gastronomic tourism-a search for local food experiences, Nutrition \& Food Science, vol. 44, no. 4, pp. 294-309, Emeraldinsight, United Kingdom.

4. Čatić, I. (2016): Uloga gastronomskih manifestacija u turističkoj ponudi Istre, Sveučilište Jurja Dobrile, Odjel za interdisciplinarne, talijanske i kulturološke studije, Pula, Hrvatska.

5. Correia, A., Moital, M., Da Costa, C. F., Peres, R. (2008): The determinants of gastronomic tourists'satisfaction: a second-order factor analysis, Journal of foodservice, vol. 19, no. 3, pp. 164-176, John Wiley \& Sons, Hoboken, New Jersey, United States.

6. Cvijanović, D., Ružić, P. (2017), Ruralni turizam, Fakultet za hotelijerstvo i turizam u Vrnjačkoj Banji, Vrnjačka Banja, Srbija.

7. Everett, S., Aitchison, C. (2007): Food tourism and the regeneration of regional identity in Cornwall: An exploratory case study, in Aitchison, C., Pritchard, A. (eds.) Festivals and Events: Culture and Identity in Leisure, Sport and Tourism, pp. 167-192, Leisure Studies Association, Eastbourne, United Kingdom. 
8. Fox, R. (2007): Reinventing the gastronomic identity of Croatian tourist destinations, Hospitality Management, vol. 26, no. 3, pp. 546-559, Elsevier, Amsterdam, Netherlands.

9. Hall, C.M., Mitchell, R. (2002): The changing nature of the relationship between cuisine and tourism in Australia and New Zealand: from fusion cuisine to food networks, in Hjalager, A.M., Richards, G. (eds.), Tourism and Gastronomy, pp. 188-206, Routledge, London, United Kingdom.

10. Hjalager, A. M., Richards, G. (eds.). (2002): Tourism and gastronomy, Routledge, London, United Kingdom.

11. Janković-Milić, V. (2016): Implikacije demografskih promena u Republici Srbiji na makro varijable i nacionalnu konkurentnost, u Krstić, B. (ur.), Faktori konkurentnosti Republike Srbije, str. 53-86, Ekonomski fakultet u Nišu, Niš, Srbija.

12. Kalenjuk, B., Tešanović, D., Gagić, S. (2015): Offer of Authentic Food as a Condition for Gastronomic Tourism Development, The European Journal of Applied Economics, vol. 12, no. 2, pp. 27-34, Walter de Gruyter, Berlin, Germany.

13. Kalenjuk, B., Tešanović, D., Škrinjar, M., Vuksanović, N. (2011): Gastronomski potencijal Vojvodine u funkciji turizma, Zbornik radova Departmana za geografiju, turizam i hotelijerstvo, Br. 40/2011, str. 180-187, Prirodno-matematički fakultet, Novi Sad, Srbija.

14. Kivela, J. J., Crotts, J. C. (2009): Understanding travelers' experiences of gastronomy through etymology and narration, Journal of Hospitality \& Tourism Research, vol. 33, no. 2, pp. 161-192, SAGE Publishing, California, United States.

15. Kivela, J., Crotts, J. C. (2005): Gastronomy tourism: A meaningful travel market segment, Journal of Culinary Science \& Technology, vol. 4, no. (2-3), pp. 39-55, Taylor \& Francis Group, United Kingdom.

16. Kostić, M., Petrović, M. (2015): Navike studenata u potrošnji brze hrane na teritoriji Vrnjačke Banje, 10. Nacionalna konferencija o kvalitetu života, str. B31-B36, Fakultet inženjerskih nauka u Kragujevcu, 4-6 jun, 2015, Kragujevac, Srbija.

17. Mason, M. C., Paggiaro, A. (2012): Investigating the role of festivalscape in culinary tourism: The case of food and wine events, Tourism management, vol. 33, no. 6, pp. 13291336, Elsevier, Amsterdam, Netherlands.

18. National Tourism Orgnisation of Serbia (2017): Events 2017, Belgrade, Serbia, (available at: http://www.serbia.travel/upload/documents/brosure/2017/events2017.pdf)

19. Radovic, G., Pejanovic, R., Njegovan, Z., Kosic, K. (2012): Event tourism as a potential generator of development of the rural tourism in the Republic of Serbia, Proceedings from the Third International Scientific Symposium “Agrosym Jahorina 2012”, Jahorina, Bosnia and Hercegovina, pp. 698-704.

20. Sahin, Ö., Aydin, A. (2017): A Cultural, Gastronomic, and Touristic Asset: The Kuşadasl Oleatrium Olive and Olive Oil History Museum Case, Journal of Tourism and Gastronomy Studies, vol. 5, no. 4, pp. 180-199, Faculty of Tourism, Department of Gastronomy and Culinary Arts, Ankara, Turkey.

21. Santich, B. (2004): The study of gastronomy and its relevance to hospitality education and training, International Journal of Hospitality Management, vol. 23, no. 1, pp. 15-24, Elsevier, Amsterdam, Netherlands.

22. Sormaz, U., Akmese, H., Gunes, E., Aras, S. (2016): Gastronomy in tourism, Procedia Economics and Finance, vol. 39, pp. 725-730, Elsevier, Amsterdam, Netherlands. 
23. Statistical Office of the Republic of Serbia (2017): Monthly Statistical Bulletin. Services (Catering trade and tourism, Transport and communications), Belgrade, Serbia, (available at: http://www.stat.gov.rs/WebSite/repository/documents/00/02/45/87/MSB-01-2017.pdf)

24. Statistical Office of the Republic of Serbia (2017a): Statistical Yearbook of the Republic of Serbia, Tourism and catering trade, Belgrade, Serbia (available at: http://www.stat.gov.rs/ WebSite/repository/documents/00/02/64/14/16-Turizam.pdf)

25. Štimac, L. (2016): Marketing u gastronomskom turizmu, Sveučilište Jurja Dobrile, Fakultet ekonomije i turizma „Dr. Mijo Mirković“, Pula, Hrvatska.

26. Stojanović, D. (2013): Gastronomija kao faktor razvoja ruralnog turizma, Univerzitet Singidunum, Beograd, Srbija.

27. Vrančić, M. (2016): Uloga manifestacija u kreiranju turističke ponude destinacije, Sveučilište Jurja Dobrile, Fakultet ekonomije i turizma „Dr. Mijo Mirković“, Pula, Hrvatska.

28. Vujko, A., Petrović, M. D., Dragosavac, M., Ćurčić, N., Gajić, T. (2017): The linkage between traditional food and loyalty of tourists to the rural destination, Teme, vol. XLI, no. 2, pp. 475-487, University of Niš, Niš, Serbia.

29. Vukić, M. (2015): Model optimalnog tržišnog pozicioniranja u turizmu baziran na preferencijama turista, doktorska disertacija, Fakultet organizacionih nauka, Beograd, Srbija.

30. Wargenau, A., Che, D. (2008): Wine tourism development and marketing strategies in Southwest Michigan, International Journal of Wine Marketing, vol. 18, no. 1, pp. 45 - 60, Emeraldinsight, United Kingdom. 


\title{
GASTRONOMSKE MANIFESTACIJE KAO FAKTOR UNAPREĐENJA TURISTIČKE PONUDE SRBIJE
}

\author{
Tanja Stanišic ${ }^{4}$, Marija Kostićn ${ }^{5}$ Milena Mišeljićc ${ }^{6}$
}

\begin{abstract}
Sažetak
Pod uticajem globalizacije $i$ masovnog nastanjivanja gradova $i$ urbanih sredina, sve više se oseća nostalgija za tradicionalnim i ruralnim. Sve ovo ide u prilog razvoju manifestacionog i gastronomskog turizma i promociji autohtonih proizvoda i tradicije. Srbija je zemlja u kojoj živi veliki broj nacionalnih manjina, gde svaka od njih ima uticaja na gastronomiju podneblja. Kombinacija svih kuhinja i raznolikost tradicije učinili su srpska jela jedinstvenim. U turističkoj ponudi Srbije postoji veliki broj manifestacija čija su tema gastronomski proizvodi. Manifestacije, kao vid promocije određenog podneblja, postaju sve popularnije $i$ brojnije. U radu su analizirane gastronomske manifestacije kao važan segment turističke ponude Srbije. Metode primenjene u radu su metod korelacione i komparativne analize. Rezultati istraživanja ukazuju na pozitivnu međuzavisnot između broja manifestacija i turističkog prometa $u$ toku godine, dok nije uočeno postojanje međuzavisnosti između broja manifestacija $i$ turističkog prometa po regionima.
\end{abstract}

Ključne reči: manifestacije, gastronomija, turizam

4 Dr Tanja Stanišić, docent, Univerzitet u Kragujevcu, Fakultet za hotelijerstvo i turizam u Vrnjačkoj Banji, Vojvođanska bb, 36210 Vrnjačka Banja, Srbija, Telefon: +381 648199022 , E-mail: tanja.stanisic@kg.ac.rs

5 Dr Marija Kostić, docent, Univerzitet u Kragujevcu, Fakultet za hotelijerstvo i turizam u Vrnjačkoj Banji, Vojvođanska bb, 36210 Vrnjačka Banja, Telefon: +381 648199009 , E-mail: marija.kostic@,kg.ac.rs

6 Ms.C. Milena Mišeljić, Agencija za obrazovanje "Akademija” Čačak, Vojvode Stepe 44, 32000 Čačak, Srbija, Telefon: +381 64 2172648, E-mail: m85milena@yahoo.com 